\title{
27. ORGANIC PETROGRAPHY AND EXTRACTABLE HYDROCARBONS OF SEDIMENTS FROM THE NORTHERN PHILIPPINE SEA, DEEP SEA DRILLING PROJECT LEG 58
}

Jürgen Rullkötter, Pierre Flekken, and Dietrich H. Welte, Institute for Petroleum and Organic Geochemistry, Kernforschungsanlage Jülich, Jülich, Federal Republic of Germany

\begin{abstract}
The quantity, type, and maturity of organic matter of Quaternary and Tertiary sediments from the Philippine Sea (DSDP Leg 58; Sites 442-446) were determined. Hydrocarbons in lipid extracts were analyzed by capillary-column gas chromatography. Kerogen concentrates were investigated by microscopy for vitrinite reflectance values and maceral composition.

In the Shikoku Basin sediments (Sites 442, 443, and 444), organiccarbon values range between 0.03 and 0.44 per cent. The higher values in the younger sediments are interpreted as an indication of increasing deposition of eroded organic particles during the past $4 \mathrm{~m} . \mathrm{y}$. Microscopic analyses revealed a dominance of reworked organic matter. Primary material could not be distinguished readily; thus, no maturation trend could be established. Extract yields were low. $N$-alkane distributions mostly show maxima at $n-\mathrm{C}_{29}$ and $n-\mathrm{C}_{31}$ and high odd-over-even predominances, typical of material which originated in terrigenous higher plants.

The organic-carbon values of sediments of the Daito Ridge and Basin region (Sites 444 and 445 ) range from less than 0.01 to 0.05 per cent. $\mathrm{N}$-alkanes exhibit varying marine and terrigenous influences. Some carbonate-rich samples show a pronounced even-over-odd predominance. At least the older sediments contained less recycled organic matter than the Shikoku Basin samples. The maturity, where measurable, was low.

None of the Philippine Sea samples indicates a significant hydrocarbon-generation potential.
\end{abstract}

\section{INTRODUCTION}

During DSDP Leg 58, five holes were drilled in the northern Philippine Sea (Figure 1). Sites 442, 443, and 444 are on two different clastic wedges in the Shikoku Basin which were recognized from seismic studies during DSDP Leg 31 (Murauchi and Asanuma, 1974, 1977; Karig, Ingle, et al., 1975). The sedimentary material of these clastic wedges is supposed to have been derived from different sources. The western wedge (Site 442) presumably originated from the Kyushu-Palau Ridge, whereas the eastern wedge (Sites 443 and 444 ) could have been derived from the Iwo Jima Ridge (Figure 1). The age of the predominantly hemipelagic sediments recovered in the Shikoku Basin during Leg 58 ranges from early Miocene to Holocene.

Sites 445 and 446 are in a small basin on the eastern side of the Daito Ridge and in the Daito Basin south of the Daito Ridge, respectively (Figure 1). The stratigraphic section at Site 445 consists of middle-Eocene to Quaternary sediments, whereas early-Eocene to Pliocene sediments were recovered at Site 446. Eocene sediments at both locations consist mainly of terrigenous mudstones, siltstones, and sandstones deposited by sub- aqueous gravity processes such as slumping, debris flows, and turbidity currents. The post-Eocene sections at Sites 445 and 446 are dominated by pelagic sediments.

The present study attempts to relate both the soluble and the insoluble organic matter in the sediments to the sedimentary history of the northern Philippine Sea.

\section{SAMPLES}

Nine core samples from the Shikoku Basin and 10 core samples from the Daito Ridge and Basin region were studied. Information on depth, stratigraphy, and lithology are given in Tables 1 and 2, respectively.

\section{EXPERIMENTAL PROCEDURES}

Samples arrived frozen. Details about the experimental procedures applied during extraction, liquid chromatography, organic-carbon determination, gas chromatography, mass spectrometry, and microscopy are described in a previous report by Rullkötter et al. (in press).

Because of the low organic-particle concentrations in most of the sediment samples, some of the samples had to be combined for microscopic analysis (Table 3). Combination was performed only within single strati- 


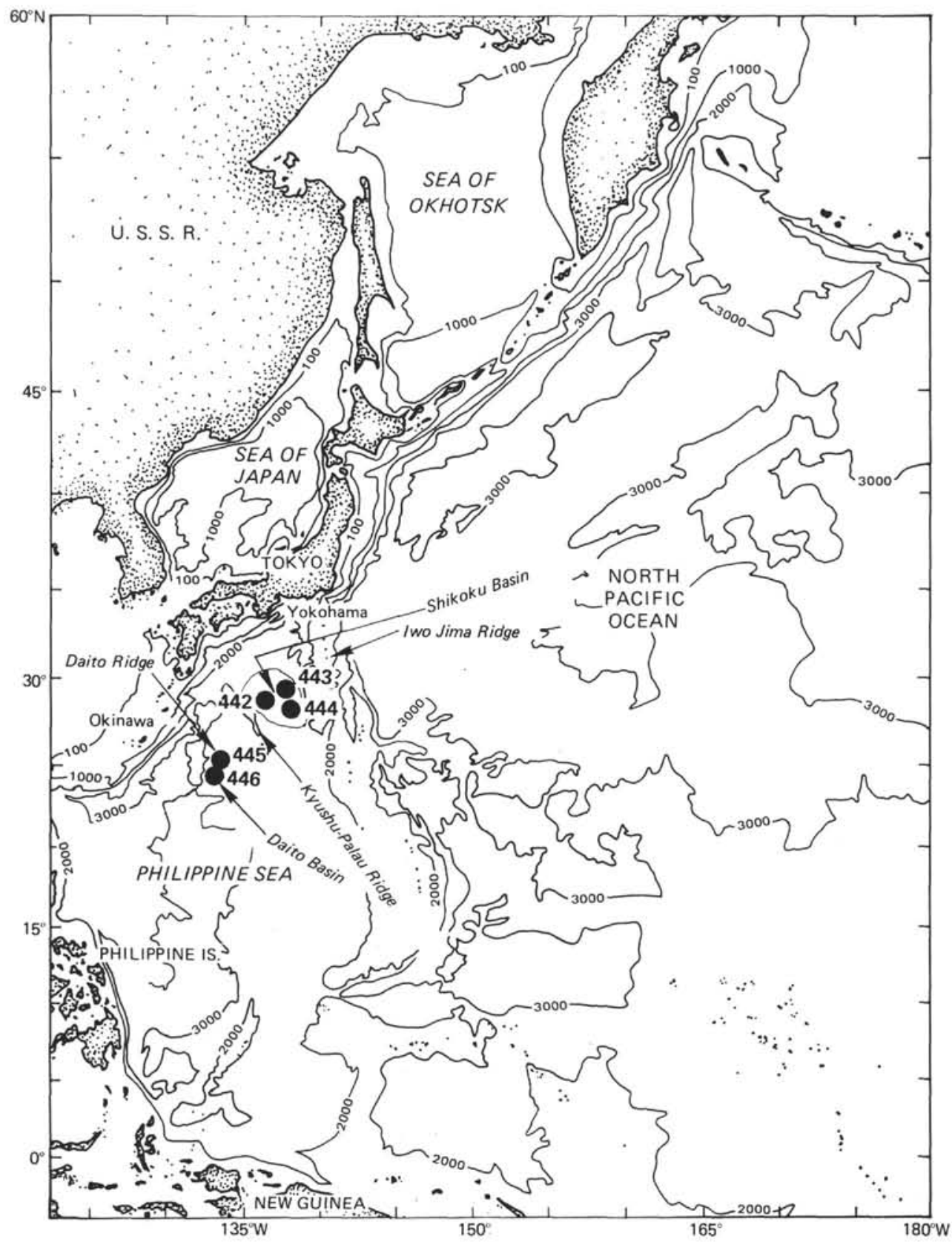

Figure 1. Location map of DSDP Leg 58 drill sites in the northern Philippine Sea: Shikoku Basin (Sites 442, 443 and 444) and Daito Ridge and Basin region (Sites 445 and 446).

graphic units. Even then, the number of data points was so low that a special technique had to be applied. After each series of reflectance measurements on the polished surfaces of the embedded kerogen concentrates, the top layer was removed, and the newly exposed surface was polished again. In that way, the number of data points was increased by exposing and measuring new kerogen particles from deeper layers of the kerogen concentrate.

Due to the low organic-particle concentrations, the mineral matrix could not be removed completely from the rock samples. Thus, because huminites, vitrinites ${ }^{1}$, inertinites, and mineral components are opaque in transmitted light, it was not possible to estimate the lip-

\footnotetext{
${ }^{1}$ The term vitrinite used in bituminous-coal terminology is synonymous with the term huminite used for brown coals or lignites. The distinction is generally made between huminite $\left(<0.5 \% \bar{R}_{\mathrm{o}}\right)$ and vitrinite $\left(>0.5 \% \vec{R}_{\mathrm{o}}\right)$ (Stach et al., 1975). We will use vitrinite throughout this text if reference is made to the huminite/vitrinite range.
} 
TABLE 1

Organic-Carbon Values and Extract Data for DSDP Leg 58 Samples from the Shikoku Basin

\begin{tabular}{|c|c|c|c|c|c|c|}
\hline $\begin{array}{c}\text { Sample } \\
\text { (interval in } \mathrm{cm} \text { ) }\end{array}$ & $\begin{array}{l}\text { Depth } \\
\text { (m) }\end{array}$ & Age & Lithology & $\begin{array}{c}\text { Organic Carbon } \\
\text { (wt. \%) }\end{array}$ & $(\mathrm{ppm})^{\mathrm{I}}$ & $\begin{array}{l}\operatorname{tract}^{\mathrm{a}} \\
(\mathrm{mg} / \mathrm{g} \mathrm{C} \\
\text { org }\end{array}$ \\
\hline $442 \mathrm{~A}-2-3,133-143$ & 13.9 & late Pleistocene/Holocene & silty clay & 0.37 & 90 & 24 \\
\hline $442 \mathrm{~A}-14-2,125-135$ & 126.3 & Pleistocene & clay & 0.21 & 55 & 26 \\
\hline $442 \mathrm{~A}-23-2,100-120$ & 211.6 & early Pliocene/late Miocene & clay & 0.09 & 16 & 18 \\
\hline $442 \mathrm{~B}-2-3,125-150$ & 279.9 & early Miocene & clay & 0.14 & 8 & 6 \\
\hline $443-9-4,125-140$ & 79.3 & early Pleistocene & carbonate mud & 0.39 & 21 & 5 \\
\hline $443-34-2,140-150$ & 313.9 & late Miocene & ashy mudstone & 0.06 & 98 & 163 \\
\hline $444-2-4,119-134$ & 11.8 & late Pleistocene & mud & 0.44 & 56 & 13 \\
\hline $444 \mathrm{~A}-9-3,115-130$ & 162.2 & late Miocene & siliceous mud & 0.04 & 12 & 30 \\
\hline $444 \mathrm{~A}-22-5,125-140$ & 269.8 & middle Miocene & claystone & 0.03 & 7 & 23 \\
\hline
\end{tabular}

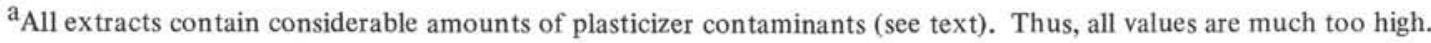

TABLE 2

Organic-Carbon Values and Extract Data for DSDP Leg 58 Samples from the Daito Ridge and Basin Region

\begin{tabular}{|c|c|c|c|c|c|c|}
\hline $\begin{array}{c}\text { Sample } \\
\text { (interval in } \mathrm{cm} \text { ) }\end{array}$ & $\begin{array}{l}\text { Depth } \\
\text { (m) }\end{array}$ & Age & Lithology & $\begin{array}{c}\text { Organic Carbon } \\
\text { (wt. \%) }\end{array}$ & $(\mathrm{ppm})^{\mathrm{E}}$ & ${ }_{\left(\mathrm{mg} / \mathrm{g} \mathrm{C}_{\text {org }}\right)}$ \\
\hline $445-6-5,119-134$ & 53.8 & late Pliocene & nannofossil ooze & 0.05 & 17 & 34 \\
\hline $445-27-4,94-109$ & 251.5 & late Miocene & nannofossil chalk & 0.02 & 11 & 55 \\
\hline $445-47-4,100-115$ & 441.6 & late Oligocene & nannofossil chalk & 0.01 & 4 & 40 \\
\hline $445-60-3,125-140$ & 563.8 & late Eocene & siliceous marly chalk & 0.01 & 3 & 30 \\
\hline $445-75-4,100-110$ & 707.6 & middle Eocene & calcareous mudstone & 0.03 & 3 & 10 \\
\hline $445-83-3,140-150$ & 782.5 & middle Eocene & sandy mudstone & 0.03 & 5 & 17 \\
\hline $446-9-4,140-150$ & 74.0 & early Miocene & pelagic clay & 0.04 & 4 & 10 \\
\hline $446-24-2,140-150$ & 213.5 & middle Eocene & mudstone & 0.04 & 24 & 60 \\
\hline $446-34-5,115-125$ & 312.7 & middle Eocene & mudstone & $<0.01$ & 8 & $>80$ \\
\hline $446 \mathrm{~A}-10-2,118-128$ & 451.7 & early Eocene & claystone & 0.04 & 4 & 10 \\
\hline
\end{tabular}

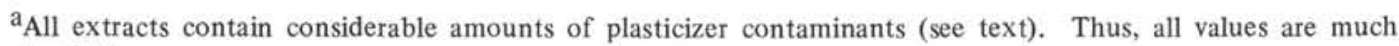
too high.

TABLE 3

Kerogen Reflectance and Compositional Data for DSDP Leg 58 Samples

\begin{tabular}{|c|c|c|c|c|c|c|c|c|c|}
\hline \multirow[b]{2}{*}{ Sample } & \multirow[b]{2}{*}{ Stratigraphy } & \multicolumn{3}{|c|}{ Mean reflectance $\left(\bar{R}_{\mathrm{O}}\right)^{\mathrm{a}}$} & \multicolumn{5}{|c|}{$\begin{array}{l}\text { Maceral Composition } \\
\qquad(\%)\end{array}$} \\
\hline & & Huminite & Vitrinite(I) & Vitrinite(II) & Lipt. & Hum. & Vitr.(I) & Vitr.(II) & Inert. \\
\hline \multicolumn{10}{|c|}{ Shikoku Basin } \\
\hline $\begin{array}{l}442 A-2-3 \\
442 A-14-2 \\
443-9-4 \\
444-2-4\end{array}$ & Pleistocene/Holocene & $0.41(7)$ & $0.69(9)$ & {$[1.38]^{\mathrm{c}}(8)$} & 12 & 6 & 7 & 8 & 67 \\
\hline $\begin{array}{l}443-34-2 \\
444 \mathrm{~A}-9-3 \\
444 \mathrm{~A}-22-5\end{array}$ & middle/late Miocene & $<0.51(-)^{\mathrm{b}}$ & $>0.5(-)^{b}$ & - & - & - & - & - & - \\
\hline $442 B-2-3$ & early Miocene & $0.37(17)$ & $0.62(30)$ & {$[1.07]^{\mathrm{c}}(8)$} & 2 & 14 & 23 & 7 & 54 \\
\hline \multicolumn{10}{|c|}{ Daito Ridge and Basin region } \\
\hline $445-6-5$ & late Pliocene & $<0.5(-)^{b}$ & - & - & - & - & - & - & - \\
\hline $\begin{array}{l}445-60-3 \\
445-75-4 \\
446-24-2 \\
446 A-10-2\end{array}$ & Eocene & $0.35(14)$ & {$[0.73]^{c}(4)$} & - & 9 & 42 & 12 & - & 37 \\
\hline
\end{tabular}

aNumber of measurements in parentheses.

bEstimates from transmitted-light observations.

${ }^{\mathrm{c}}$ Low accuracy due to scattered data points. 
tinite content from the smear slides. Consequently, the polished specimens were used for calculating the amount of liptinites, vitrinites, and inertinites present (maceral composition). However, the quantitative data have to be interpreted with care. This is also true for the maceral distributions (Figure 2; Table 3), because small liptinite and inertinite particles could not be measured.

The vitrinite-reflectance value, where quoted, is the arithmetic mean of the values in the lowest histogram peak in the vitrinite distributions generated using 0.05 per cent $R_{\mathrm{o}}$ intervals (cf. Figure 2).

\section{RESULTS AND INTERPRETATIONS}

\section{Shikoku Basin}

The total organic-carbon contents of all samples from the Shikoku Basin are fairly low (Table 1), but they exhibit a general trend with depth. About 0.4 per cent $\mathrm{C}_{\text {org }}$ was determined for shallower sediments. This value decreases to about 0.1 per cent $C_{\text {org }}$ or less below 200 meters sub-bottom depth. This is in good agreement with the shipboard organic-carbon determinations. The decrease of organic carbon can be correlated with sediment age rather than depth; the decrease ceased at a sediment age of about $4 \mathrm{~m} . \mathrm{y}$. The shipboard scientific party suggested that anaerobic bacteria capable of operating to at least 200 meters sediment depth might be responsi- ble for the decrease in organic-carbon content. Because a similar effect is not observed in areas where distal sedimentation in oxygen-containing waters is comparable to sedimentation in the Shikoku Basin (e.g., in the Japan Trench; Rullkötter et al., in press), we would like to suggest an alternative explanation.

The microscopy of all samples from Holes 442, 443, and 444 revealed kerogens dominated by terrigenous plant debris. The maceral composition and the reflectance values of combined and single samples are given in Table 3. For Sample 442B-2-3, 125-150 cm (early Miocene), transmitted-light observation revealed the presence of one moderately dark-brown spore. The lowest huminite-reflectance peak shows a mean reflectance of 0.37 per cent. A second peak, given as vitrinite (I) in Table 3, was observed with 0.62 per cent $\bar{R}_{\mathrm{o}}$, and a third broad distribution contained vitrinites between 0.82 and 1.50 per cent $\bar{R}_{\mathrm{o}}$ (Table 3 , vitrinite (II); Figure $2 b)$. The higher vitrinite-reflectance peaks and the brown color of the spore indicate the presence of reworked organic particles. The combined middle/late Miocene sample from the Shikoku Basin did not yield enough kerogen particles for reflectance measurements. By smear-slide observation in transmitted light, a moderately dark-brown spore was detected, indicating likewise reworked organic material. The only indication of primary organic material was gained from a light-
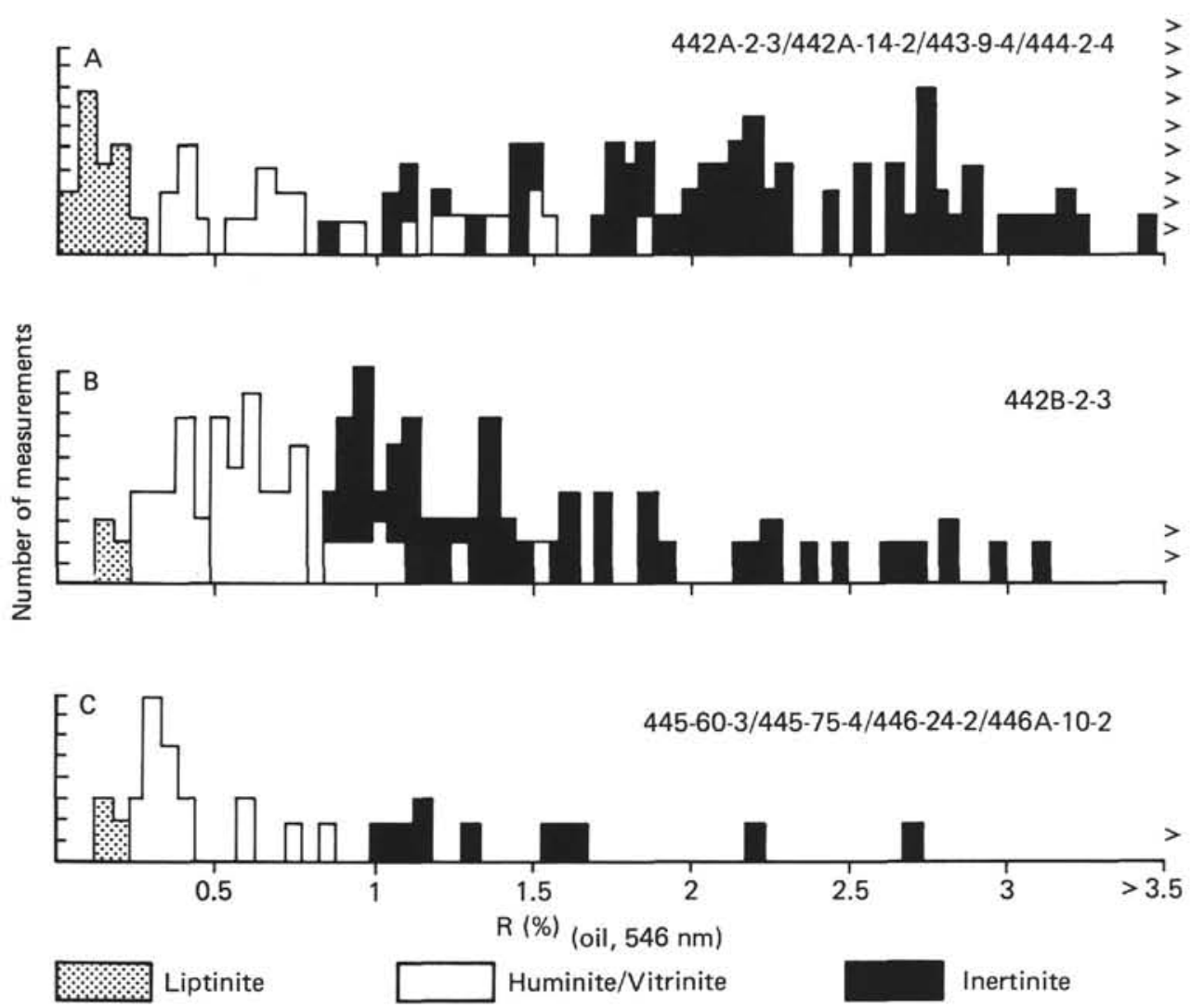

Figure 2. Maceral-reflectance histograms of kerogen particles. A. Combined sample from the Pleistocene/Holocene of the Shikoku Basin. B. Sample from the Miocene of the Shikoku Basin. C. Combined sample from the Eocene of the Daito Ridge and Basin region. 
yellow, translucent algal or spore-derived disk which was only partly preserved. In the combined Pleistocene/Holocene sample, some light-yellow, translucent spore/pollen particles could be distinguished from darker particles of the same type. Also, a few light-yellow, translucent cuticles were found. The mean huminite reflectance was determined to be 0.41 per cent $\bar{R}_{\mathrm{o}}$, and two additional vitrinite peaks were measured at 0.69 per cent $\bar{R}_{\mathrm{o}}$, and 1.38 per cent $\bar{R}_{\mathrm{o}}$, respectively (Table 3 ; Figure 2a). Similar bimodal distributions have been reported for the Japan Trench sediments of Legs 56 and 57 (Rullkötter et al., in press).

From the reflectance data obtained for all the samples from the Shikoku Basin holes it seems likely that nearly all the organic matter has been eroded and redeposited. Even the reflectance values of the lowest vitrinite peaks do not show a reasonable depth trend. Also, there are no indications of an increase in reflectance of vitrinite by partial oxidation (no brighterreflecting oxidation rims with darker inner cores were observed), which could have covered the reflectance trend. Thus, it cannot even be concluded definitely that the lowest-reflecting material is all primary. The totalmaceral-reflectance histograms (Figure 2a, b) show that most of the organic particles consist of inertinites, which especially in the Pleistocene/Holocene sample (Figure 2a) reach very high reflectance levels. Because of its overall composition, the organic matter is not well suited as nutrient for micro-organisms. The increase in organic carbon from sediments $4 \mathrm{~m} . \mathrm{y}$. old to those of Recent age can be explained if one assumes from the Pliocene onward an increase in erosion of high-maturity organic matter (at least partly coals, as indicated by a trimacerite $\left[\bar{R}_{\mathrm{o}} 0.52-0.61 \%\right.$ ] found in the combined Pleistocene/Holocene sample), which was then transported to the Shikoku Basin.

The predominant inertness of the organic matter in all sediment samples from the Shikoku Basin is also confirmed by solvent extraction. Extract yields are generally low, and it should be emphasized that the figures given in Table 1 are much too high, since investigation of the aromatic-hydrocarbon and polar fractions by gas chromatography/mass spectrometry shows them to be dominated by plasticizer contaminants. Phthalate and sebacate patterns are similar to those reported by Simoneit (1975), who assumed that they originated from the plastic core liner. Thus, no figures for the relative proportions of chromatographic fractions are given.

From the capillary-column gas chromatograms of the non-aromatic hydrocarbons, normalized $n$-alkane distributions were determined (Figure 3). There is not such a uniform pattern as found in the Japan Trench (Rullkötter et al., in press) but $n$-alkane distributions typical of terrigenous organic matter, with maxima at $n-\mathrm{C}_{29}$ or $n-\mathrm{C}_{31}$ (Eglinton and Hamilton, 1963), and with high CPI values (Table 4), dominate here as well. This seems to be somewhat more pronounced for samples derived from the eastern clastic wedge (Holes 443 and 444). In contrast, some samples from Site 442 (442A-14-2, 125$135 \mathrm{~cm}$; 442B-2-3, 125-150 cm) show a much higher concentration of $n$-alkanes at the lower-molecularweight end, with maxima around $n-\mathrm{C}_{17}$. These varying $n$-alkane distributions are in accordance with results for samples from Site 297 (DSDP Leg 31) on the third (northern) clastic wedge in the Shikoku Basin (Ames and Littlejohn, 1975). Pristane/phytane ratios (Table 4) are always above unity, indicating a predominantly oxic depositional environment (Didyk et al., 1978). Sample 444A-22-5, 125-140 cm, which shows the most-uniform $n$-alkane distribution, might have been affected by a diabase sill found about 15 meters above; however, no further evidence could be gained from microscopic measurements because of the need for sample combination.

\section{Daito Ridge and Basin Region}

Total organic-carbon values for sediments of the Daito Ridge and Basin region show a maximum of 0.05 per cent $\mathrm{C}_{\text {org }}$ (Table 2); thus, they are extremely poor in organic carbon. Accordingly, all organic-matter data should be judged with great care. Extract yields (Table 2) are very low, too, and only the non-aromatic hydrocarbons could be analyzed in detail, because the more-polar fractions mainly consist of phthalates and sebacates - probably from the core liner - as in the Shikoku Basin samples.

The $n$-alkane distributions of the Daito Ridge sediments (Site 445) exhibit a varying influence of terrigenous higher-plant material and marine organic matter (Figure 4). Some of the samples (445-47-4, 100-115 cm; $445-60-3,125-140 \mathrm{~cm} ; 445-75-4,100-110 \mathrm{~cm})$ show a fairly pronounced even-over-odd predominance of $n$-alkanes in the range $n-C_{15}$ to $n-C_{22}$ (Figure 4; Table 5) which can be related to the high carbonate content in these sediments. Other cases are known from the literature where diagenesis of organic matter in carbonate facies produces $n$-alkanes with similar evenover-odd predominances (Welte and Waples, 1973; Dembicki et al., 1976). The pristane/phytane ratios vary between 0.8 and 1.7 (Table 5), which may indicate anoxic as well as oxic depositional environments (Didyk et al., 1978). The $n$-alkane data for the Daito Basin samples (Figure 4; Table 5) do not show any pronounced dominance and cannot be interpreted readily.

Two samples from the Daito Ridge and Basin region were investigated microscopically. The combined Eocene sample showed some light-yellow and some moderately dark- to dark-brown spore/pollen particles in transmitted light. A number of light-yellow, translucent cuticles and the light-yellow spore/pollen indicate both the terrigenous nature and the low maturity of the organic matter. The reflectance measurements (Figure 2c; Table 3) showed a lower peak with a mean huminite reflectance of 0.35 per cent $\bar{R}_{\mathrm{o}}$ and a peak with a mean vitrinite reflectance of 0.73 per cent $\vec{R}_{\mathrm{o}}$ indicating recycled organic material. As can be seen from Figure 2, the amount of high-reflectance inertinites is much lower than in the Shikoku Basin samples. This shows that, at least during Eocene times, the transport of recycled organic matter into the Daito Ridge and Basin region was less than later in the Shikoku Basin. From comparison of the total organic-carbon contents, it can probably be 

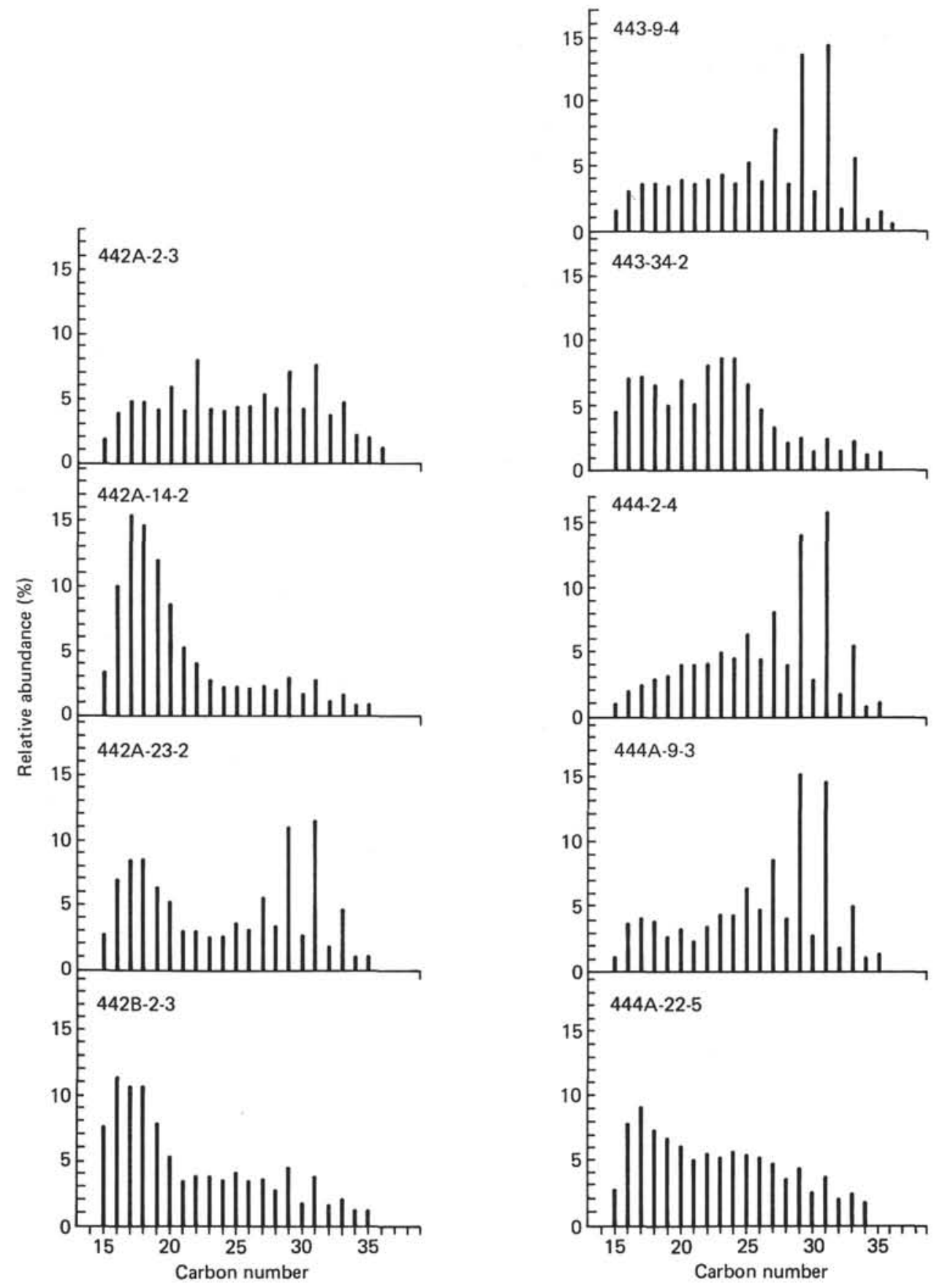

Figure 3. Normalized n-alkane distribution for samples from DSDP Sites 442, 443, and 444 (Shikoku Basin).

concluded that generally more recycled organic matter has been deposited in the Shikoku Basin that in the Daito Ridge and Basin region. A more-direct comparison is not possible, because the Pliocene samples did not yield enough kerogen particles for reflectance measurements. In transmitted light, only one light-yellow liptinite particle indicating low maturity was observed.

\section{HYDROCARBON POTENTIAL}

The investigated Philippine Sea sediments do not show significant potential for hydrocarbon generation.
The low organic-carbon content and the inertness of the organic matter indicate that the sediments were deposited under "normal case" deep-sea conditions, which are unfavorable for the preservation of large quantities of lipid organic material (Welte et al., 1979).

\section{ACKNOWLEDGMENTS}

We thank the technical staff of the Institute for Petroleum and Organic Geochemistry at the Kernforschungsanlage Jülich for their valuable assistance. Our thanks also go to Dr. M. Bjor $\varnothing y$ (Continental Shelf Institute, Trondheim, Norway) and 
TABLE 4

Carbon Preference Indexes (CPI) and Pristane/Phytane Ratios for Non-Aromatic Hydrocarbon Fractions of DSDP Leg 58 Samples from the Shikoku Basin

\begin{tabular}{lrcccc}
\hline Sarople & $\begin{array}{c}\text { Depth } \\
(\mathrm{m})\end{array}$ & $\mathrm{CPI}_{19-23}$ & $\mathrm{CPI}_{25-31}$ & Pristane/n-C 17 & Pristane/Phytane \\
\hline $442 \mathrm{~A}-2-3$ & 13.9 & 0.68 & 1.44 & 0.57 & 1.8 \\
$442 \mathrm{~A}-14-2$ & 126.3 & 1.04 & 1.48 & 0.34 & 1.9 \\
$442 \mathrm{~A}-23-2$ & 211.6 & 0.92 & 2.80 & 0.36 & 2.1 \\
$442 \mathrm{~B}-2-3$ & 279.9 & 0.98 & 1.53 & 0.27 & 1.4 \\
$443-9-4$ & 79.3 & 0.98 & 3.01 & 0.59 & 2.1 \\
$443-34-2$ & 313.9 & 0.83 & 1.21 & 0.34 & 1.2 \\
$444-2-4$ & 11.8 & 1.02 & 3.02 & 0.63 & 1.8 \\
$444 \mathrm{~A}-9-3$ & 162.2 & 0.87 & 3.08 & 0.35 & 1.1 \\
$444 \mathrm{~A}-22-5$ & 269.8 & 0.94 & 1.22 & 0.23 & 1.4 \\
\hline
\end{tabular}

Dr. C. Cornford (The British National Oil Corporation, Glasgow, Scotland) for carefully reading and reviewing the manuscript.

Samples were made available by participation of the Deutsche Forschungsgemeinschaft (DFG) in the DSDP/IPOD program. This is gratefully acknowledged, as well as financial support by the German Ministry for Research and Technology (BMFT), Grant No. ET 3070 B.

\section{REFERENCES}

Ames, R. L., and Littlejohn, R., 1975. Diagenesis of organic matter and estimated temperature history from carbonization measurements, Shikoku Basin. In Karig, D. E., Ingle, J. C., Jr., et al., Init. Repts. DSDP, 31: Washington (U.S. Govt. Printing Office), pp. 621-627.

Dembicki, H., Jr., Meinschein, W. G., and Hattin, D. E., 1976. Possible ecological and environmental significance of the predominance of even-carbon number $\mathrm{C}_{20}-\mathrm{C}_{30} n$-alkanes. Geochim. Cosmochim. Acta, 40, 203-208.

Didyk, B. M., Simoneit, B. R. T., Brassell, S. C., and Eglinton, G., 1978. Organic geochemical indicators of palaeoenvironmental conditions of sedimentation. Nature, 272, 216-222.

Eglinton, G., and Hamilton, R. J., 1963. The distribution of alkanes. In Swain, T. (Ed.), Chemical Plant Taxonomy: London (Academic Press), pp. 187-217.

Karig, D. E., Ingle, J. C., et al., 1975. Init. Repts. DSDP, 31: Washington (U.S. Govt. Printing Office).

Murauchi, S., and Asanuma, T., 1974. Seismic reflection profiles and sonobuoy refraction measurements during GDP-6 to 8 voyages. Mar. Sci., 6, 23-27.

1977. Seismic reflection profiles in the western $\mathrm{Pa}$ cific, 1965-1974: Tokyo (University of Tokyo Press).

Rullkötter, J., Cornford, C., Flekken, P., and Welte, D. H., in press. Organic geochemistry of sediments cored during Deep Sea Drilling Project Legs 56 and 57, Japan Trench: Organic petrography and extractable hydrocarbons. In Langseth, M., Okada, H., von Huene, R., Nasu, N., et al., Init. Repts. DSDP, 56, 57, Pt. 2: Washington (U.S. Govt. Printing Office).

Simoneit, B. R. T., 1975. Sources of organic matter in ocean sediments, Ph. D. thesis, University of Bristol.

Stach, E., Mackowski, M. Th., Teichmüller, M., Taylor, G. H., Chandra, D., and Teichmüller, R., 1975. Stach's Textbook of Coal Petrology (2nd Ed.): Berlin (Gebrüder Borntraeger).

Welte, D. H., Cornford, C., and Rullkötter, J., 1979. Hydrocarbon source rocks in deep sea sediments. In Proc. 11th Ann. Offshore Technology Conf., Houston (Vol. 1), pp. 457-464.

Welte, D. H., and Waples, D. W., 1973. Über die Bevorzugung geradzahliger $n$-Alkane in Sedimentgesteinen. Naturwissenschaften, $60,516-517$. 

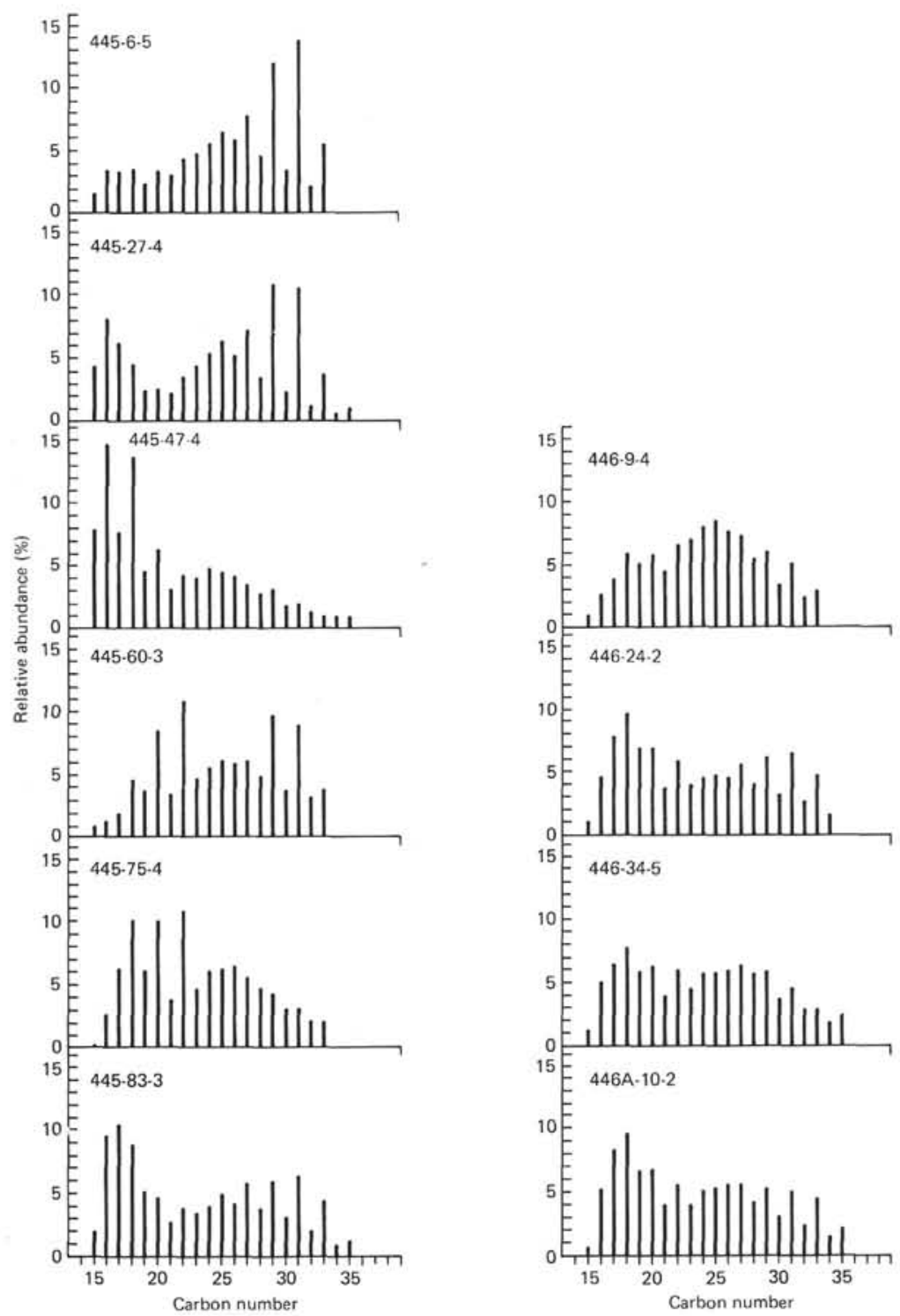

Figure 4. Normalized n-alkane distributions for samples from DSDP Sites 445 and 446 (Daito Ridge and Basin region).

TABLE 5

Carbon Preference Indexes (CPI) and Pristane/Phytane Ratios for Non-Aromatic Hydrocarbon Fractions of DSDP Leg 58 Samples from the Daito Ridge and Basin Region

\begin{tabular}{lrcccc}
\hline Sample & $\begin{array}{c}\text { Depth } \\
(\mathrm{m})\end{array}$ & $\mathrm{CPI}_{19-23}$ & $\mathrm{CPI}_{25-31}$ & Pristane/n-C 17 & Pristane/Phytane \\
\hline $445-6-5$ & 53.8 & 0.84 & 2.23 & 0.40 & 1.4 \\
$445-27-4$ & 251.5 & 0.84 & 2.45 & 0.34 & 1.7 \\
$445-47-4$ & 441.6 & 0.63 & 1.09 & 0.40 & 1.5 \\
$445-60-3$ & 563.8 & 0.49 & 1.63 & 0.39 & 0.8 \\
$445-75-4$ & 707.6 & 0.52 & 1.05 & 0.28 & 0.9 \\
$445-83-3$ & 782.5 & 0.77 & 1.60 & 0.23 & 1.5 \\
$446-9-4$ & 74.0 & 0.86 & 1.26 & 0.36 & 0.9 \\
$446-24-2$ & 213.5 & 0.75 & 1.50 & 0.24 & 1.0 \\
$446-34-5$ & 312.7 & 0.76 & 1.17 & 0.35 & 1.7 \\
$446 \mathrm{~A}-10-2$ & 451.7 & 0.76 & 1.28 & 0.28 & 1.1 \\
\hline
\end{tabular}

